\title{
Lavar as mãos contra o Coronavírus: mas, e a Água?
}

Denise Morado Nascimento

\section{RESUMO}

Este artigo discute a necessidade do acesso à agua para o enfrentamento da COVID19 e o cumprimento das recomendações do Observatório Nacional dos Direitos à Água e ao Saneamento (ONDAS) da Universidade de Brasília (UnB).

Palavras-chave: COVID-19; Pandemia; Atenção Primária à Saúde; Água.

\section{ABSTRACT}

This article discusses the need for access to water in order to confront of COVID-19 and compliance with the recommendations of the National Observatory on Water and Sanitation Rights (ONDAS) of the University of Brasilia (UnB).

Keywords: COVID-19; Pandemic; Primary Health Care; Water.
Revista da Rede APS 2020

Publicada em: 15/04/2020

DOI:10.14295/aps.v2i1.61

Denise Morado Nascimento (Escola de Arquitetura da Universidade Federal de Minas Gerais, IEAT/UFMG, Minas Gerais, Brasil).

Correspondência para: Denise Morado Nascimento dmorado@gmail.com 
A crise global de enfrentamento ao Covid-19 parece ser momento para observar números da desigualdade no Brasil, onde 56,2\% da população abaixo da linha da pobreza, definida pelo Banco Mundial como aquela que tem renda per capita de US\$1,90/dia, não têm acesso a esgotamento sanitário; 25,8\% (13,5 milhões) não são atendidos com abastecimento de água por rede; $21,1 \%$ (11,1 milhões) não têm coleta de lixo (dados 2018) ${ }^{1}$; e 49,9\% da região norte e $48,1 \%$ da região nordeste tem rendimento médio de até meio salário mínimo, dados de $2017^{2}$. As desigualdades também variam em função do território e da população, segmentados por cor ou raça: entre as pessoas com os $10 \%$ menores rendimentos, $78,5 \%$ são pretos ou pardos contra $20,8 \%$ de brancos (dados 2017) ${ }^{3}$. No Sudeste, pretos ou pardos representam 46,4\% da população com rendimentos, mas sua participação entre os $10 \%$ com maiores rendimentos é de $16,4 \%{ }^{4}$.

Nesse momento da expansão da COVID-19, é preciso perguntar: o que fazer? O Ministério da Saúde, em consonância com a Organização Mundial da Saúde, vem fortemente recomendando uma principal medida para reduzir o contágio pelo coronavírus: lavar as mãos.

Entretanto, lavar as mãos não é possibilidade para 35 milhões de brasileiros que não tem acesso à água, de acordo com o Instituto Trata Brasil ${ }^{5}$. O país vem enfrentando, ao longo de sua história, dois grandes desafios: (i) garantir o abastecimento de água tanto para um expressivo contingente populacional, concentrado em um número reduzido de cidades de grande porte quanto para um número maior de pequenas cidades dispersas em todo o território nacional, e, (ii) atender municípios de pequeno porte por meio de suas Prefeituras, geralmente com capacidade institucional limitada ${ }^{6}$.

Não bastasse o avanço do coronavírus no país, os municípios brasileiros vêm registrando ocorrências de endemias ou epidemias de doenças associadas às condições precárias de saneamento básico: dengue, diarreia, verminoses, chikungunya, zika, doença do aparelho respiratório, dermatite, hepatite, leptospirose, difteria, malária, febre amarela, cólera, tifo ${ }^{7}$. O Instituto Trata Brasil afirma que, em 2017, 258 mil internações foram feitas por doenças de veiculação hídrica ${ }^{8}$.

Outro aspecto importante sobre a possibilidade de transmissão do coronavírus é a enorme carga viral despejada nos rios na medida em que "70\% dos 5.570 municípios brasileiros possuem remoção de, no máximo, 30\% da carga orgânica gerada" ${ }^{\prime 9}$. A possibilidade de transmissão fecooral "poderá aumentar a disseminação do SarsCoV-2 no ambiente e a infecção da parcela mais vulnerável da população, que não tem acesso a infraestrutura adequada de saneamento básico", diz Nota técnica do INCT ETES Sustentáveis ${ }^{10}$.

Diante desse cenário, espera-se que políticas públicas emergenciais em territórios assim caracterizados sejam conduzidas por governos municipais e estaduais, apoiados por organizações não-governamentais e entidades voluntárias. Parece ser natural, para não dizer óbvio, que se medidas estratégicas relativas ao acesso à água e ao saneamento são tomadas, a capacidade de organização dos serviços nas redes públicas de saúde melhora.

Assim, faz-se urgente efetivarmos as recomendações feitas pelo Observatório Nacional dos Direitos à Água e ao Saneamento (ONDAS), da Universidade de Brasília (UnB), aqui sintetizadas $^{11}$ :

(1) suspender por um período de quatro meses os cortes de fornecimento de água devido a inadimplência do usuário, bem como reconectar aquelas famílias que atualmente têm suas ligações cortadas por inadimplência;

(2) interromper a cobrança das contas de água por um período de quatro meses, para os segmentos mais pobres e vulneráveis da população;

(3) assegurar água de forma regular, em quantidade suficiente e com qualidade adequada, às comunidades que habitam em ocupações nas áreas centrais e periféricas das 
Nascimento, D. M.

cidades, bem como em localidades e assentamentos rurais;

(4) interromper procedimentos de redução da pressão de redes de água que abastecem comunidades, favelas e periferias onde vivem famílias mais vulneráveis, sem renda ou com trabalho precarizado;

(5) expandir o abastecimento para as áreas não atendidas das favelas e periferias;

(6) garantir o abastecimento de água e o esgotamento sanitário nas unidades de saúde, inclusive as emergenciais;

(7) assegurar o abastecimento de água, esgotamento sanitário e disponibilidade de equipamentos para realização da higiene pessoal em asilos e demais residências comunitárias que abrigam idosos com baixa capacidade financeira, bem como cadeias e presídios;

(8) criar estratégias emergenciais para garantir a saúde da população em situação de rua, em especial com relação às demandas de água e provimento de condições para realização da higiene diária e de alimentação;

(9) apoiar os pequenos municípios e as comunidades rurais que operam diretamente seus serviços públicos de saneamento;

(10) assegurar informação ampla sobre os direitos à água e ao saneamento. 


\section{NOTAS E REFERÊNCIAS}

${ }^{1} \mathrm{NERY}, \mathrm{C}$. Extrema pobreza atinge 13,5 milhões de pessoas e chega ao maior nível em 7 anos. 07/11/2019. Agência IBGE. Disponível em: <https://agenciadenoticias.ibge.gov.br/agencia-noticias/2012-agencia-denoticias/noticias/25882-extrema-pobreza-atinge-13-5-milhoes-de-pessoas-e-chega-ao-maior-nivel-em7-anos> Acesso em: 20 nov. 2019.

2 IBGE. Perfil dos municípios brasileiros Saneamento básico: aspectos gerais da gestão da política de saneamento básico. Rio de Janeiro: IBGE, 2018.

3 IBGE. Síntese de indicadores sociais: uma análise das condições de vida da população brasileira, 2017. Rio de Janeiro: IBGE, 2017.

${ }^{4}$ Idem.

${ }^{5}$ Ver: http://www.tratabrasil.org.br

6 Atlas Brasil: abastecimento urbano de água: panorama nacional / AgênciaNacional de Águas; Engecorps/Cobrape. - Brasília: ANA: Engecorps/Cobrape, 2010.

7 IBGE. Perfil dos municípios brasileiros Saneamento básico: aspectos gerais da gestão da política de saneamento básico. Rio de Janeiro: IBGE, 2018.

${ }^{8}$ Ver: http://www.tratabrasil.org.br

${ }^{9}$ Atlas Esgotos: despoluição de bacias hidrográficas / Agência Nacional de Águas, Secretaria Nacional de Saneamento Ambiental . Brasília: ANA, 2017. p. 22.

10 Ver: <https://ufmg.br/comunicacao/noticias/pesquisadores-da-ufmg-alertam-para-efeitos-depresenca-do-novo-coronavirus-no-esgoto $>$

${ }^{11}$ Ver "Carta Aberta à sociedade brasileira - Observatório Nacional dos Direitos à Água e ao Saneamento -ONDAS e a epidemia do COVID-19 no Brasil", 27/03/2020. Disponível em <https://ondasbrasil.org/wpcontent/uploads/2020/03/Carta-\%C3\%A0-Sociedade-Brasileira-completa.pdf> 